\title{
New Contexts for Early Tudor Plays: William Briton, an Early Reader of Gorboduc
}

LAURA EsTILL

Early Theatre 16.2 (2013), 197-210

DOI: http://dx.doi.org/10.12745/et.16.2.12

\begin{abstract}
By examining William Briton's extracts from Gorboduc in the Houghton manuscript (BL Add MS 61822), Estill shows how the political valences of Sackville and Norton's play changed in relation to the Elizabethan succession crisis. This essay explores the play's afterlife in Briton's commonplace book, contextualized as both a political guidebook and literary work. Briton's manuscript offers hitherto overlooked evidence of one early modern reader's response to Gorboduc. Ultimately, Estill contends that we should consider early Tudor drama in changing historical contexts and not as fixed works tied solely to an original moment of publication and performance.
\end{abstract}

Scholars often position Thomas Sackville and Thomas Norton's Gorboduc, Or Ferrex and Porrex as a first: the first Senecan-style English play, the first blank-verse drama, the 'first real English tragedy', the first English play we know of that includes a dumb show - this play is even considered the first English work to undergo serious literary criticism. ${ }^{1}$ Current scholarship tends to focus on the play's advice to Queen Elizabeth, its political impact when it was first performed, and the meaning it would have had for audience members; indeed, Gorboduc is one of the few early English plays where we have documented evidence of a playgoer's response. ${ }^{2}$ I argue that we must consider Gorboduc not just in its initial moment of performance, but also in later moments when it was read. In this essay, I trace one early reader's response to Gorboduc as registered in his manuscript miscellany where he copied selections from the play. William Briton of Kelston (1564-ca 1636) extracted sections from Gorboduc that show he read the play for commonplaces and political advice while also positioning it as a literary text. Understanding Briton's manuscript requires maintaining two historical points of focus: the original circumstances of the play's composition and performance as well as the later moment when Briton encountered the text. This essay explores both the commonplace/decontextualized aspects of Briton's extracts, and the particular/recontextualized circumstances of Briton's manuscript and moment

Laura Estill (lestill@tamu.edu) is the assistant professor of Digital Shakespeare Studies at Texas A\&M University, where she has recently joined the World Shakespeare Bibliography. 
of reading Gorboduc. Though in the early 1560s, when this play was first written and performed, Queen Elizabeth had time to make a match, by the time Briton was copying selections, likely the early 1590s, Elizabeth was over fifty and would have been unable to bear children. ${ }^{3}$

Gorboduc's publication history, like Briton's manuscript, suggests that we need to consider this work in multiple historical contexts. Gorboduc was first presented at the Inner Temple during the 1561 Christmas festivities and then acted before Queen Elizabeth in January 1562. First published in 1565 (Q1), Sackville and Norton's play was republished with slight changes in 1570 (Q2) and 1590 (Q3). ${ }^{4}$ Even though Gorboduc had been in print for decades, Briton is the first known person (and to date, the only known early modern manuscript compiler) to copy excerpts from Sackville and Norton's play. Briton was a friend of Sir John Harington (who also hailed from the village of Kelston in Somerset); both Briton and Harington were members of the Sidney circle. Briton's extracts from Gorboduc are found in the Houghton manuscript (BL Additional Ms 61822). Although the Houghton manuscript has received considerable attention because it contains an almost-complete version of Sidney's Astrophil and Stella, the extracts from Gorboduc, like many other dramatic extracts from this period, have been overlooked.

The Houghton manuscript passed from John Briton, who used it as an account book, to his son William on his death. ${ }^{5}$ The contents are as follows: legal notes (ff 1-54v), followed by 'Rules of husbandry' (ff 55-62v), 'Pithie sentences and wise sayinges' (ff 77-90v), Astrophil and Stella (ff 91-103), then more rules of husbandry (ff 104v-9) and miscellaneous notes (ff 113-16). ${ }^{6}$ Briton copied three pages of extracts from Gorboduc in the 'Pithie sentences' section of his manuscript, demonstrating his interest in reading the play as a source of commonplaces, those short, well-phrased expressions of insight or wisdom. Some of the extracts Briton selected are indeed commonplaces; for instance, the first selection Briton chose to copy is Ferrex's 'a cawsles wronge \& so vniust dispight / maie haue redresse or at the least revenge' (f $89 \mathrm{v}$; 1.1.12-13). Briton changed Ferrex's 'such causeless wrong' to 'a causeless wrong', making the saying applicable not only to Gorboduc's plan to divide his kingdom, but to more generally unjust situations. Briton generalized the quote so it would apply beyond the context of the play; that is, he broadened Ferrex's particular words into a commonplace.

The 1570 edition of Gorboduc was printed with commonplace markers, typographical indicators for readers to take the words of the play and memorize or copy them. ${ }^{7}$ In fact, the commonplace markers are a less-touted 'first' 
for this groundbreaking play: it is the first known published play to include commonplace markers. ${ }^{8}$ Briton did not copy the passages highlighted for extracting by commonplace markers, and we cannot ascertain which edition he read because of the similarity between the quartos. Whether or not Briton's copy of the play had those marginal inverted commas to draw his eye to particular sections, he engaged in the kind of reading Q2 printer John Day encouraged. The inclusion of commonplace markers in the second edition of Gorboduc suggests that, as early as 1570, play readers both sought and were led to passages that could be taken separately from the original performed context. Commonplace markers pointed readers to sententious passages; they should point us as critics to consider commonplacing readers. This is not to say that early readers approached plays seeking only the timeless wisdom of commonplaces: the title pages of all three early quartos remind buyers that part of the play's importance is that it was acted before the queen. Commonplace markers in printed plays indicate the necessity of a multifocused scholarship that explores the anticipated reader response this typographical practice elicited as well as the evidence of readers interacting with early modern plays by copying extracts.

Briton's interest in Gorboduc's sententious wisdom intersects with the play's advice genre. He approached other political guidebooks the way he read Gorboduc, seeking 'sentences' and 'wise sayinges' to copy: the 'Pithie sentences and wise sayinges' section (ff 77-90v) contains extracts from, among others, William Baldwin's Treatise of Moral Philosophy. Baldwin's full title, A Treatise of Moral Philosophy Containing the Sayings of the Wise, highlights the importance of learning through commonplaces. ${ }^{9}$ By the time Briton was compiling his manuscript, Baldwin's book had been through more than ten reprints, with added information on the title page that reinforced the message even further: wherein you may see the worthy and pithy sayings of philosophers, emperors, kings, and orators. Briton copied from the section of Baldwin's book often titled 'of preceptes and counsayles', ${ }^{10}$ including sententiae from Seneca, Solon, Plato, and others, for instance, Periander's advice to 'performe whatsoeuer thou promysest, or not promyse' (f 83v). ${ }^{11}$ Briton also chose excerpts from popular political guidebooks, including Erasmus's In Praise of Folly, Marcello Palingenio's The Zodiake of Life, and Thomas Blenerhasset's The Seconde Part of the Mirrour for Magistrates, before leading directly into the Gorboduc extracts. The Seconde Part of the Mirrour for Magistrates, like Gorboduc, is a text directly concerning political downfall, 'conteining the falles of the infortunate Princes of this Lande. ${ }^{12}$ Palingenio's Zodiake is similarly 
didactic, 'disclosing the haynous Crymes \& wicked vices of our corrupt nature' that, through negative examples, will be 'both pleasaunt \& profitable' for readers. ${ }^{13}$ Briton read Sackville and Norton's play for commonplaces just as he read other books that were specifically marketed as moralizing.

Briton opened the 'Pithie sentences' section of his manuscript by describing and translating selections from Andrea Alciato's Emblemata (1531), the earliest emblem book, which reinforces both the moral and modular nature of many texts Briton read. ${ }^{14}$ Emblem books, like The Treatise of Moral Philosophy and printed commonplace books, were designed not to be taken as a whole, but in parts. Such books encouraged readers to seek only the information they needed and did not require reading from start to finish. Alciati's emblems were frequently republished (in at least fourteen editions between 1531 and 1577 alone) in different orders, further underscoring the text's inherent modularity. Even though Briton extracted lines from Gorboduc, with one exception, in the order they appear in the text (see Appendix A), much like his selections from The Seconde Part of the Mirrour for Magistrates, he approached the play as something that could be fragmented and decontextualized. Scholars recognize that discontinuous reading was a common mode of textual engagement in the early modern period, but we rarely consider plays as texts that people read in this manner. ${ }^{15}$ Though he likely read Gorboduc continuously, Briton's extracts and marginalia adapt the singular play-text into multiple texts that, like emblems and commonplaces, do not rely on a particular order or continuous reading practice to make sense.

Briton's marginalia emphasizes the modularity of his extracts in two ways: his topical headings make it easier to find particular sections at a glance, and they encapsulate the message of the extract so that it can be easily understood without the rest of the play. For instance, Briton copied Porrex's

yf euer greife, yf euer woefull harte might move regrate, with sorowe of his falt I thinke the torment of my mornefull case knowen vttwardlie as I do fele the same would force evin wrathe her self to pittie me but as the water trobled with the mudd shewes not the face which els the eye should see euin so your Irefull mynd with stirred thought cannot so perfittlie decearne my cawse but this vnhapp amongst so many heapes 
I must content me with most wreched man that to my self I must referr my woe in pyninge thoughte of myne accursed fact.

In the context of the play, Porrex begins the speech by announcing he is guilty of murder, 'Neither, O King, I can or will deny / But that this hand from Ferrex life hath reft' (35-6), but the particulars of Porrex's fratricide are not Briton's focus. Rather, Briton applies the speech to broader themes: 'Remorse of consyenc in [a] malefactour Described' (f 90). Briton's 'malefactour' need not even have committed a violent crime as this extract begins immediately after Porrex imagines repenting 'his bloody fact' (44). Similarly, Briton removes Porrex's mention of his interlocutor, 'your grace' (46), and generalizes it to 'uttwardlie' ( $\mathrm{f} 90$ ): the importance is not the particular interpersonal relation of a son and father, or that the king knows of the crime, but rather that the torment is public. Briton's generalizations make Sackville and Norton's text applicable to many situations, like the other commonplaces and emblems he copied in this section of his manuscript.

By decontextualizing parts of Gorboduc, Briton highlighted both their potential timelessness and their ability to be recontextualized. Briton's miscellany offers new intertexts and the particular historic context of the early 1590s. In 1590, Edward Allde printed the third edition of Gorboduc with a modernized version of Lydgate's politically moralizing The Serpent of Deuision. ${ }^{16}$ Allde and the stationer, John Perrin, marketed these texts as valuable precisely because they relate the tales of Rome's fall and Britain's slide into a fictitious civil war: 'England take heede', the title page announces. The epistle to the reader explicitly pointed to the didactic value of comparing the present situation with the past: 'thou wilt find if thou compare our state with Romes, to be no lesse in danger and dread'. ${ }^{17}$ Gorboduc was not mired in its 1560s origins. If the play's lesson in 1561 was for Elizabeth to marry and produce an heir, the lesson in the early 1590s stressed the importance of choosing and announcing an heir. Allde and Perrin's republication, like Briton's extracts, show the need to consider Gorboduc as a play of the 1590 s as much as of the 1560 s.

Gorboduc addressed a contentious issue when it was written, but the stakes were even higher when Briton read the play. In 1587, Peter Wentworth wrote a letter that circulated in manuscript addressed to the queen arguing that she needed to select her successor; in 1593, when Queen Elizabeth discovered the letter she ordered all copies destroyed and had Wentworth jailed. ${ }^{18}$ The 
posthumously published 1598 version, A Pithie Exhortation to her Maiestie for Establishing her Successor to the Crowne, included a quotation on the title page, 'A wise Prince by naming his heire will provide for the safetie of his kingdome: and if hee have no sonne, he will be the more carefull to establish his sucessor', which mirrors (both inverting and reinforcing) the message in Gorboduc's argument: 'And afterwards, for want of issue of the Prince, whereby the succession of the crown became uncertain, they fell to civil war. ${ }^{19}$ Robert Waldegrave, who published the Exhortation anonymously, asserted the urgency of the matter in his epistle to the reader: 'it is absolutelie necessarie that al the claimes and titles to the crowne of this Realme be tried by Parliament, and that the rightful sucessour be declared and confirmed nowe in to her Maiesties life-time'. ${ }^{20}$ When Sackville and Norton wrote Gorboduc, the issue at stake was the queen's marriage: by the time Briton read the play, the concern was about naming an heir. In one sense, the play could be read as hindsight lamenting that Elizabeth never did marry, but in another, Gorboduc still served as a warning to prevent 'civil war' that would leave 'the land for a long time desolate and miserably wasted'. ${ }^{21}$

Many of the extracts that Briton copied from Gorboduc about the succession crisis can be applied to the particular situation in Sackville and Norton's play, to the 1560 s, and to the 1590 s because of their commonplace nature. Briton copied most of the first chorus, including the warning that 'eche Chainge of corse unioynte the whole estate / \& yelds yt thrale to ruyne by debate' (f $89 \mathrm{v}, 1.2 .74-5$ ). Briton's marginal title, 'the differenc betwene vnyon $\&$ diuysion', contrasts the 'setled stay' and 'steedfast place by knowen \& doubtles Reighte' with a 'Disioyned' country that falls to 'forrene power of mightie foes' (f $89 \mathrm{v}, 1.2 .370,371,369,377$ ). Ultimately, the 'former force dothe lose'; a divided country will fall ( $\mathrm{f} 89 \mathrm{v}, 1.2 .369$ ). Briton's later selection from the Chorus, which he titled 'usurped Reigne', emphasizes the perils of civil war brought about by unclear succession as well as the troubles that face a ruler whose position is not clear: 'bloddie slaughter doth prepare the way / to fatall Septer \& accursed Reigne' (f 90, 3.1.175-6). Briton copied Sackville and Norton's caution that vying for the throne reveals the worst of humanity, as

The lust of kingdomes knoweth no sacred fayth no Rule of Reason no regard of Right no kindlie loue no feare of heauens wrath. 
The succession crisis looms as large in Briton's manuscript as it does in the play itself.

Though the years from 1560 to 1590 witnessed court rivalries, antagonisms, and intrigues, historians point to the 1590s as a particularly rocky time in Elizabeth's court because of factions vying for power. ${ }^{22}$ Briton's selections highlight the dangers brought about by those who strive for favour and power:

when growing pryd dothe fill the swelling brest

$\&$ greedie lust doth rayse the clymminge mynde

oh hardlie may the perrill be represt

ne feare of angry goods ne lawes kynd

ne contry care cann fiery harte restraine

when force hath armed envie $\&$ disdaine. $\quad$ (f $90,2.2 .89-94)^{23}$

It is difficult to imagine Briton copying these extracts without thinking of Raleigh, Essex, Cecil, or even the recently-deceased Dudley. The passages from Gorboduc about ambition no longer resonate with those aiming to marry the queen, but rather with those vying for power both in the queen's final years and after her inevitable death:

when cruel hart wrath Treason, $\&$ dysdaine within the ambitious brest are lodged then behold howe myschiefe wyde herself displaies. (f 90v, 4.2.269-72)

Briton's extracts are powerful precisely because they can be applied to contemporary situations in compelling ways.

Briton was, perhaps unsurprisingly, interested in the role of the advisors to the throne: he copied the play's caution to advisors to 'be plain without all wrie respect / or poysonous craft to speake in pleasing wyse' (f $89 \mathrm{v}$, 1.2.29-30). Briton noted in the margin, 'a councellour' next to Gorboduc's explanation of his decision to give each of his sons an advisor:

I meane to ioyne to eithere of my Sonnes some one of those whose longe approved faithe $\&$ wysdome tryed maie well assure my harte that myninge frawd shall fynde no waie to creepe into their fenced [ye] eares with grave advyse. (f 89v, 1.2.360-4)

On the facing page Briton copied, 'wo to the prynce that plyant eare enclynes I \& yelds his mynde to poysonous tale that floweth / from flattering mouth' 
(f 90, 2.2103-5), further warning about the perils of poor counsel. Among the first extracts from the play that interested Briton was the claim by Arostus (one of Gorboduc's advisors) that if Gorboduc gave the throne to his sons while he still lived, he could 'guyd \& traine in tempered staie / their yet grene bending wittes' ( $\mathrm{f} 89 \mathrm{v}, 1.2 .117-21$ ). For the last selection he copied from this play - the only extract not copied in its original order - Briton chose the words of one of Gorboduc's faithful advisors, Eubulus, upon hearing that the royal line has ended: ' $\&$ loe the entry to the wofull wrack / \& vtter Ruyne' (f 90v, 5.2.181-2). Eubulus's despair offers a bleak conclusion to 'Pithie sentences' section of the manuscript that reflects the uncertainty of Briton's times as much as it captures the distant fictitious past of the tragedy and Sackville and Norton's concerns about succession.

Eubulus's lamenting words face the opening of Sir Philip Sidney's Astrophil and Stella (ff 91-103): ${ }^{24}$ Briton's manuscript arrangement not only aligned Gorboduc with early modern political advice books but also situated these dramatic extracts alongside a major vernacular poetic work. At the time Briton was writing his manuscript, Sidney was regarded as a national hero and Protestant martyr, as well as one of England's foremost writers. By placing the extracts from Gorboduc alongside the sonnets from Astrophil and Stella, Briton perhaps cast the play in a literary light while also highlighting the English-ness (and perhaps Protestant-ness) of the play and the political issues it touches like the role of advisors to the crown. The extracts from Gorboduc, untitled, appear as a group at the end of the 'Pithie sentences' section, before Briton's heading signaled the change in topic and Sidney's social status: 'Sonnetts written by Sir Phillipp Sydney knight'. Briton did not treat Gorboduc in precisely the same way as Astrophil and Stella (from which he copied complete sonnets rather than snippets and commonplaces), but he could have chosen to place the extracts in another section of this manuscript, or perhaps in another manuscript. For centuries, Gorboduc has been placed in an elevated literary lineage from Seneca to Shakespeare, appearing in our anthologies and theatre history textbooks. ${ }^{25}$ Because of its many firsts and critical heritage, modern scholars take for granted that Sackville and Norton's play is a literary contribution, but the play's position as a distinctly literary text would not have been immediately apparent to its earliest readers and audience members. Both Astrophil and Stella and Gorboduc can be seen as catalysts for two genres that gained popularity while Briton was writing: sonnet sequences and history plays. The 1591 publication of Astrophil and Stella precipitated the 1590 s vogue for sonnet sequences. ${ }^{26}$ History plays flourished 
in the 1590s, including Shakespeare's tetralogies and King John, as well as plays by Marlowe, Greene, Peele, and Munday. Briton's choice of Gorboduc reflects not only the politics of his era and the rising prestige of history plays, but also contemporary literary tastes.

Paul Whitfield White has argued that 'political plays' from 'pre-playhouse England', like Gorboduc, are "closed" texts, that is to say, texts designed to induce a pre-conceived range of responses in a clearly defined group of spectators.' ${ }^{27}$ White admits, however, that all plays contain 'indeterminacies in meaning: ${ }^{28}$ the Houghton manuscript reveals that one of the indeterminacies in meaning that we need to look at is the changing meaning plays have when read in different historical circumstances. Vita Sackville-West once described her ancestor's play as 'the first and most boring tragedy of the English language', ${ }^{29}$ but Briton's manuscript demonstrates that Gorboduc was still read and valued as political advice decades after its initial performance. Jonson famously asserted that Shakespeare's work was not of an age, but for all time; Briton's extracts encourage us to consider other early modern plays in the same way. The play's republications and Briton's decontextualized extracts reveal that Gorboduc is not of one age, but of many. Tracing how early readers commonplaced from plays is not to seek the universal. Rather, the recontextualization of Briton's extracts, and other dramatic extracts, point scholars to new times to consider, which can ultimately give us a different understanding of the play. By placing selections from this play alongside sonnets from Astrophil and Stella and commonplaces from political guidebooks, Briton shows that he respected Gorboduc both as a literary work and as a political commentary. Briton's commonplacing and emblems show that he valued the play not as a complete, unified, artistic vision, or even as a performance. Briton's manuscript proves that we can and should read Gorboduc as more than a recommendation for Elizabeth to marry. Gorboduc's appearance in print and manuscript remind scholars that early Tudor plays do not stay, well, early Tudor; we can and should attend to the afterlives of these works and how their political valences and literary impact changed over time.

Much work remains to be done on dramatic extracts from Tudor plays in manuscript. Many of these extracts are uncatalogued, but as scholars digitize and transcribe more early modern manuscripts, they will surely discover more examples. Online searchable digital editions of early Tudor texts (from PDFs of nineteenth-century books on The Internet Archive to the latest borndigital scholarly editions on Digital Renaissance Editions) will make it easier to identify unknown passages in commonplace books and verse miscellanies. ${ }^{30}$ 
Even those few extracts of early plays that are catalogued are often only discussed as an afterthought in relation to Shakespearean material: for instance, while there have been many contributions on how Edward Pudsey's commonplace book presents Othello, comparatively little has been said about his reading of John Lyly's Campaspe and Love's Metamorphoses. ${ }^{31}$ The ongoing opening of the archive, both of full-text plays and of manuscripts, offers scholars the potential to consider tangible examples of reader responses to early modern plays. 


\section{Appendix A: Briton's Gorboduc Extracts}

All line numbers are taken from the Fraser and Rabkin edition of Gorboduc. Extracts are listed in the order in which they appear in the manuscript. Some extracts have marginal notations that are not noted here.

\begin{tabular}{lll} 
Folio & \multicolumn{1}{c}{ Line Numbers } & Speaker \\
\hline $89 \mathrm{v}$ & $1.1 .12-13$ & Ferrex \\
& $1.2 .29-30$ & Gorboduc \\
& $1.2 .117-21$ & Arostus \\
& $1.2 .124-32$ & Arostus \\
& $1.2 .322-3$ & Eubulus \\
& $1.2 .351-64$ & Gorboduc \\
& $1.2 .370-81$ & Chorus \\
& $2.1 .125-9$ & Hermon \\
& 2.1 .179 & Ferrex \\
& $2.2 .89-94$ & Chorus \\
& $2.2 .96-8$ & Chorus \\
& $2.2 .103-8$ & Chorus \\
& $3.1 .170-6$ & Chorus \\
& 4.2 .43 & Porrex \\
& $4.2 .142-8$ & Gorboduc \\
& $4.2 .149-58$ (continuing directly) & Arostus \\
$4.2 .159-64$ (continuing directly) & Gorboduc \\
$4.2 .223-6$ & Marcella \\
$4.2 .269-72$ & Chorus \\
$4.2 .291-5$ & Chorus \\
& $5.2 .86-91$ & Clotyn \\
& $5.2 .128-33$ & Arostus \\
& $5.2 .193-7$ & Arostus \\
& $5.2 .181-2$ & Eubulus \\
\hline
\end{tabular}

\section{Notes}

I would like to thank the Banting Postdoctoral Fellowship program and the Social Sciences and Humanities Research Council of Canada for funding this research. Thanks also to Erin Kelly, Daniel Powell, and the participants in the Early Theatre review process. 
1 Jessica Winston has recently asserted these oft-repeated claims in 'English Seneca: Heywood to Hamlet', Mike Pincombe and Cathy Shrank (eds), The Oxford Handbook of Tudor Literature, 1485-1603, (Oxford, 2009), 472-87 DOI: http://dx.doi .org/10.1093/oxfordhb/9780199205882.013.0029; as has Alice Hunt, in 'Dumb Politics in Gorboduc', Thomas Betteridge and Greg Valker (eds), The Oxford Handbook of Tudor Drama (Oxford, 2012), 547-65, DOI: http://dx.doi.org/10.1093 loxfordhb/9780199566471.013.0033. Irby B. Cauthen called Gorboduc the 'first real English tragedy' in his Regents Renaissance Drama edition (Lincoln, 1970), xiii. The Broadview Anthology of British Literature claims that '[Sidney's] assessment of the English play Gorboduc is the first sustained critical discussion of a literary work in English', Joseph Black (ed.), Concise Edn (Peterborough, 2007), 662.

2 For political readings of the play, see, among others, Hunt, 'Dumb Politics'; Dermot Cavanagh, 'Political tragedy in the 1560s: Cambises and Gorboduc', The Oxford Handbook of Tudor Literature, 488-503, DOI: http://dx.doi.org/10.1093/oxfordhb 19780199205882.013.0030; Susan Doran, Monarchy and Matrimony: The Courtships of Elizabeth (London, 1996), 55-8; and Stephen Alford, The Early Elizabethan Polity: William Cecil and the British Succession Crisis, 1558-1569 (Cambridge, 1998), 99-103. For a discussion of the politics in relation to the eyewitness account of the performance, see Henry James and Greg Walker, 'The Politics of Gorboduc', English Historical Review 110.435 (1995), 109-21 DOI: http://dx.doi.org/10.1093/ehr /CX.435.109; Greg Walker, 'Strategies of Courtship: The Marital Politics of "Gorboduc", The Politics of Performance in Early Renaissance Drama (Cambridge, 1998), 196-221, DOI: http://dx.doi.org/10.1017/CBO9780511583155.007; Norman Jones and Paul Whitfield White, 'Gorboduc and Royal Marriage Politics: An Elizabethan Playgoer's Report of the Premiere Performance', English Literary Renaissance 26.1 (1996) 3-26, DOI: http://dx.doi.org/10.1111/j.1475-6757.1996.tb01481.x; and Mike Pincomb, 'Robert Dudley, Gorboduc, and "The Masque of Beauty and Desire": A Reconsideration of the Evidence for Political Evidence', Parergon 20.1 (2003), 19-44, DOI: http://dx.doi.org/10.1353/pgn.2003.0055.

3 Briton copied the selections from Gorboduc between 1587 and 1605; William Ringler narrows the dating of this section of the manuscript to the early 1590s. Ringler's typewritten notes, 'The Houghton Manuscript of Sidney's Astrophel and Stella', are kept with this manuscript in the BL and are also available in the manuscript facsimile on British Literary Manuscripts Online.

4 Russell A. Fraser and Norman Rabkin (eds), Drama of the English Renaissance (New York, 1976), 81. All line numbers from Gorboduc and quotations not from the Houghton manuscript are taken from this edition. 
5 Henry Woudhuysen, Sir Philip Sidney and the Circulation of Manuscripts 1558-1640 (Oxford, 1996), 409.

6 For a more detailed description of the manuscript contents, see the BL catalogue and Ringler, 'The Houghton Manuscript'.

7 For an overview of the publication of commonplace markers in early modern drama, see Zachary Lesser and Peter Stallybrass, 'The First Literary Hamlet and the Commonplacing of Professional Plays', Shakespeare Quarterly 59.4 (2008), 371-420, DOI: http://dx.doi.org/10.1353/shq.0.0040. On the function of commonplace markers, see Margreta de Grazia, 'Shakespeare in Quotation Marks', Jean I. Marsden (ed.), The Appropriation of Shakespeare: Post-Renaissance Reconstructions of the Works and the Myth (New York, 1991), 57-71. I consulted facsimiles of Gorboduc Q1, Q2, and Q3 on Early English Books Online (EEBO).

8 Lesser and Stallybrass, 'First Literary Hamlet', 385.

9 I have normalized the spelling of this title as it varies from edition to edition, and Briton's particular source-text is unknown.

10 Baldwin, A Treatise of Morall Phylosophie (London, 1547; sTC 1253) EEBO, sig. Iir.

11 Briton added the final phrase to Periander's advice, 'or not promyse'.

12 Thomas Blenerhasset, The Seconde Part of the Mirrour for Magistrate (London, 1578; STC 3131), ЕEBO, title page.

13 Marcello Palingenio Stellato, The Zodiake of Life, trans. Barnabe Googe (London, 1565; sTC 19150), ЕEBO, title page. Note that The Zodiake was often republished, and we do not know Briton's exact source. On the interrelation of negative examples, tragedy, and political teaching, see Cavanagh, 'Political Tragedy', 489-95.

14 The translations of Alciato's Latin emblems are likely Briton's (Ringler, 'The Houghton Manuscript', 2). I consulted editions of Alciato from Alciato at Glasgow, www .emblems.arts.gla.ac.uk/alciato.

15 On discontinuous reading see Robert Darnton, 'Extraordinary Commonplaces', New York Review of Books (21 December 2000), 82-7 and Peter Stallybrass, 'Books and Scrolls: Navigating the Bible', Jennifer Andersen and Elizabeth Sauer (eds), Books and Readers in Early Modern England: Material Studies (Philadelphia, 2002), 42-79.

16 For more on Allde's edition and The Serpent of Division, see Maura Nolan, 'Tragedy and Comedy: Lydgate's Disguisings and Public Poetry', John Lydgate and the Making of Public Culture (Cambridge, 2005), 120-83, esp. 120-1, DOI: http://dx.doi .org/10.1017/CBO9780511483387.004.

17 'To the Gentlemen Readers', The Serpent of Deuision (London, 1590; sTC 17029), EEBO, sig. A2v. 
18 Dorothy Auchter, Dictionary of Literary and Dramatic Censorship in Tudor and Stuart England (Westport, 2001), 273-5.

19 Sackville and Norton, Gorboduc, Argument. Peter Wentworth, A Pithie Exhortation To Her Maiestie for Establishing Her Successor to the Crowne (London, 1598; STC 25245), ЕЕВо, title page.

20 Peter Wentworth, 'To the Reader', A Pithie Exhortation, sig. A2r.

21 Sackville and Norton, Gorboduc, Argument.

22 Simon Adams, Leicester and the Court: Essays on Elizabethan Politics (Manchester, 2002), esp. 13-23 and 68-94; Doran, Monarchy and Matrimony, 215-6.

23 Gloss: for 'goods' read 'Gods'.

24 Briton copied 100 of the 108 sonnets Sidney included in the 1591 edition of Astrophil and Stella. Although many of Sidney's other works circulated widely in manuscript, this manuscript is the only one to contain extensive selections from Astrophil and Stella (Martin Garrett, Sidney: The Critical Heritage [London and New York, 1996]). See also Ringler, The Poems of Sir Philip Sidney (Oxford, 1962), 541-2 and Woudhuysen's Sir Philip Sidney, 347-8, 409-10.

25 A few examples: H. Schmidt, 'Seneca's Influence upon Gorboduc', Modern Language Notes 2.2 (1887), 28-35; Michael Ullyot, 'Seneca and the Early Elizabethan History Play', Teresa Grant and Barbara Ravelhofer (eds.), English Historical Drama, 15001660: Forms Outside the Canon, (Basingstoke, 2008), 98-124, DOI: http://dx.doi .org/10.1057/9780230593268; Carneiro de Mendonça and Barbara Heliodora, 'The Influence of Gorboduc on King Lear', Shakespeare Survey 13 (1960), 41-8; and James D. Carroll, 'Gorboduc and Titus Andronicus', Notes \& Queries 51.3 (2004), 267-9, DOI: http://dx.doi.org/10.1093/nq/51.3.267. See also note 1.

26 Arthur F. Marotti, 'Love is Not Love': Elizabethan Sonnet Sequences and the Social Order', English Literary History 49.2 (1982), 396, DOI: http://dx.doi .org/10.2307/2872989.

27 Paul Whitfield White, 'Politics, Topical Meaning, and English Theatre Audiences 1485-1575', Research Opportunities in Renaissance Drama 34 (1995), 42.

28 Ibid.

29 White and Jones, 'Gorboduc and Royal Marriage Politics', 16.

30 The Internet Archive, archive.org; Digital Renaissance Editions (to be populated), digitalrenaissance.uvic.ca. For more on Digital Renaissance Editions, see Brett Hirsch's essay in this issue of Early Theatre.

31 Extracts from Lyly can be found in Pudsey's commonplace book, Bodleian ms Eng. poet. d. 3, f 86v. See Juliet Mary Gowan, 'An Edition of Edward Pudsey's Commonplace Book (ca 1600-1615) from the Manuscript in the Bodleian', MPhil thesis (University of London, 1967). 